\title{
Towards clinical implementation of circulating cell-free DNA in precision medicine
}

\author{
Wei Zhang ${ }^{1,2}$ \\ 'Department of Preventive Medicine, Northwestern University Feinberg School of Medicine, Chicago, IL 60611, USA. \\ ${ }^{2}$ The Robert H. Lurie Comprehensive Cancer Center, Northwestern University Feinberg School of Medicine, Chicago, IL 60611, USA.
}

Correspondence to: Dr. Wei Zhang, Department of Preventive Medicine, Northwestern University Feinberg School of Medicine, 680 N. Lake Shore Dr., Suite 1400, Chicago, IL 60611, USA. E-mail: wei.zhang1@northwestern.edu

How to cite this article: Zhang W. Towards clinical implementation of circulating cell-free DNA in precision medicine. J Trans/ Genet Genom 2019;3:11. https://doi.org/10.20517/jtgg.2019.07

Received: 11 Sep 2019 Accepted: 12 Sep 2019 Published: 17 Sep 2019

Science Editor: Wei Zhang Copy Editor: Jia-Jia Meng Production Editor: Tian Zhang

Precision medicine holds the promise for precise diagnosis, prognosis, treatment response monitoring, and disease surveillance. Advancing clinical diagnosis is critical for providing precise and personalized care to patients and may improve clinical outcomes for many life-threatening diseases. Especially for cancers, which are a leading cause of death globally ${ }^{[1,2]}$, early detection and precise diagnosis could provide opportunities to significantly reduce mortality as well as healthcare cost burden on the society ${ }^{[3]}$. For years, clinicians and researchers have been trying to discover better ways for more effective diagnosis and detection of cancers. At present, tissue biopsy pathology and imaging analyses are often the "gold standard" for cancer diagnosis and detection. Although extremely useful, tissue-based approaches are limited by various factors such as their invasive nature, inaccessibility to certain anatomical locations, and the issue of intra-tumoral heterogeneity, while conventional imaging-based approaches may be limited by possible exposure to radiation or lack of molecular information. For example, a particular biopsy procedure may miss the tumor or cannot capture the overall molecular features of the tumor, thus repeated biopsies are often required. Therefore, it is of urgent clinical need for the development of non-invasive or minimally-invasive approaches that can overcome those limitations associated with the current tissue- and imaging-based approaches.

During the past several years, assays based on patient-derived bodily fluids (i.e., liquid biopsy) ${ }^{[4]}$, such as circulating cell-free DNA (cfDNA) in the peripheral blood, have demonstrated promising results as a clinically convenient, minimally-invasive approach for disease diagnosis, for example early detection of

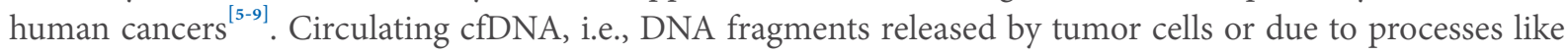
apoptosis and necrosis, offers an intriguing alternative for cancer biomarker discovery, considering that cfDNA contains tumor-derived genetic and epigenetic information ${ }^{[7,10]}$. Notably, technological advances in genetic and epigenetic profiling have begun to allow interrogation of various molecular targets contained

(C) The Author(s) 2019. Open Access This article is licensed under a Creative Commons Attribution 4.0 International License (https://creativecommons.org/licenses/by/4.0/), which permits unrestricted use, sharing, adaptation, distribution and reproduction in any medium or format, for any purpose, even commercially, as long as you give appropriate credit to the original author(s) and the source, provide a link to the Creative Commons license, and indicate if changes were made. 
in cfDNA for exploring their diagnostic potential ${ }^{[11-14]}$. Of particular interest are for example mutations and cytosine modifications (i.e., DNA methylation and hydroxymethylation) in cfDNA, although other features of cfDNA (e.g., fragmentation size) have also emerged to be useful clinical markers for diseases ${ }^{[15-17]}$. Though cancer biomarker discovery using cfDNA is expected to be probably the most active area of clinical implementation, cfDNA has also been shown to have diagnostic value for many other diseases or conditions, such as diabetic complications ${ }^{[18]}$. In this special issue "Application of circulating cfDNA in the diagnosis of human cancers and chronic diseases", we are interested in publishing research articles, short communications, technical notes, and review papers that cover the general topic of applying cfDNA in the diagnosis and detection of human cancers and other diseases. We look forward to discussing exciting progress and moving towards clinical implementation of circulating cfDNA in precision medicine.

\section{DECLARATIONS}

\section{Authors' contributions}

The author contributed solely to the article.

\section{Availability of data and materials}

Not applicable.

\section{Financial support and sponsorship}

This work was partially supported by grants from the National Institutes of Health: (Ro1CA223662), (R21MD011439), and (U01CA217078).

\section{Conflicts of interest}

The author is a shareholder of Shanghai Epican Genetech Co. Ltd, which develops cancer biomarkers.

\section{Ethical approval and consent to participate}

Not applicable.

\section{Consent for publication}

Not applicable.

\section{Copyright}

(c) The Author(s) 2019.

\section{REFERENCES}

1. Siegel RL, Miller KD, Jemal A. Cancer statistics, 2018. CA Cancer J Clin 2018;68:7-30.

2. Chen W, Zheng R, Baade PD, Zhang S, Zeng H, et al. Cancer statistics in China, 2015. CA Cancer J Clin 2016;66:115-32.

3. Siravegna G, Marsoni S, Siena S, Bardelli A. Integrating liquid biopsies into the management of cancer. Nat Rev Clin Oncol 2017;14:53148.

4. Wan JC, Massie C, Garcia-Corbacho J, Mouliere F, Brenton JD, et al. Liquid biopsies come of age: towards implementation of circulating tumour DNA. Nat Rev Cancer 2017;17:223-38.

5. Li W, Zhang X, Lu X, You L, Song Y, et al. 5-Hydroxymethylcytosine signatures in circulating cell-free DNA as diagnostic biomarkers for human cancers. Cell Res 2017;27:1243-57.

6. Xu RH, Wei W, Krawczyk M, Wang W, Luo H, et al. Circulating tumour DNA methylation markers for diagnosis and prognosis of hepatocellular carcinoma. Nat Mater 2017;16:1155-61.

7. Zeng C, Stroup EK, Zhang Z, Chiu BC, Zhang W. Towards precision medicine: advances in 5-hydroxymethylcytosine cancer biomarker discovery in liquid biopsy. Cancer Commun (Lond) 2019;39:12.

8. Cai J, Chen L, Zhang Z, Zhang X, Lu X, et al. Genome-wide mapping of 5-hydroxymethylcytosines in circulating cell-free DNA as a noninvasive approach for early detection of hepatocellular carcinoma. Gut 2019; DOI: 10.1136/gutjnl-2019-318882. [Epub ahead of print].

9. Song CX, Yin S, Ma L, Wheeler A, Chen Y, et al. 5-Hydroxymethylcytosine signatures in cell-free DNA provide information about tumor types and stages. Cell Res 2017;27:1231-42.

10. Jahr S, Hentze H, Englisch S, Hardt D, Fackelmayer FO, et al. DNA fragments in the blood plasma of cancer patients: quantitations and 
evidence for their origin from apoptotic and necrotic cells. Cancer Res 2001;61:1659-65.

11. Han D, Lu X, Shih AH, Nie J, You Q, et al. A Highly Sensitive and Robust Method for Genome-wide 5hmC Profiling of Rare Cell Populations. Mol Cell 2016;63:711-9.

12. Song CX, Szulwach KE, Fu Y, Dai Q, Yi C, et al. Selective chemical labeling reveals the genome-wide distribution of 5-hydroxymethylcytosine. Nat Biotechnol 2011;29:68-72.

13. Shen SY, Singhania R, Fehringer G, Chakravarthy A, Roehrl MHA, et al. Sensitive tumour detection and classification using plasma cellfree DNA methylomes. Nature 2018;563:579-83.

14. Gyanchandani R, Kvam E, Heller R, Finehout E, Smith N, et al. Whole genome amplification of cell-free DNA enables detection of circulating tumor DNA mutations from fingerstick capillary blood. Sci Rep 2018;8:17313.

15. Zhang Z, Zhang W. Fragmentation patterns of circulating cell-free DNA demonstrate biomarker potential for human cancers. Biotarget 2019;3:pii:16.

16. Cristiano S, Leal A, Phallen J, Fiksel J, Adleff V, et al. Genome-wide cell-free DNA fragmentation in patients with cancer. Nature 2019;570:385-9.

17. Jiang P, Sun K, Tong YK, Cheng SH, Cheng THT, et al. Preferred end coordinates and somatic variants as signatures of circulating tumor DNA associated with hepatocellular carcinoma. Proc Natl Acad Sci U S A 2018;115:E10925-33.

18. Yang Y, Zeng C, Lu X, Song Y, Nie J, et al. 5-Hydroxymethylcytosines in circulating cell-free DNA reveal vascular complications of type 2 diabetes. Clin Chem. Forthcoming 2019. 